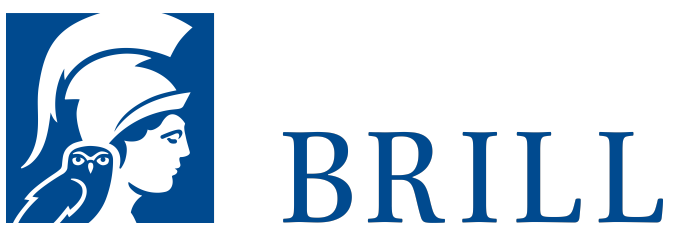

\title{
The Qurānic Pagans and Related Matters
}

Collected Studies in Three Volumes, Volume 1

Author: Patricia Crone

Editor: Hanna Siurua

Patricia Crone's Collected Studies in Three Volumes brings together a number of her published, unpublished, and revised writings on Near Eastern and Islamic history, arranged around three distinct but interconnected themes. Volume 1, The Qur'ānic Pagans and Related Matters, pursues the reconstruction of the religious environment in which Islam arose and develops an intertextual approach to studying the Qurānic religious milieu. Volume 2, The Iranian Reception of Islam: The Non-Traditionalist Strands, examines the reception of pre-Islamic legacies in Islam, above all that of the Iranians. Volume 3, Islam, the Ancient Near East and Varieties of Godlessness, places the rise of Islam in the context of the ancient Near East and investigates sceptical and subversive ideas in the Islamic world.

The Iranian Reception of Islam: The Non-Traditionalist Strands Islam, the Ancient Near East and Varieties of Godlessness

Readership

All interested in the history of Islam and the ancient and Islamic Near East, including specialists, post-graduate students, undergraduate students, educated laypeople, academic libraries, institutes, and public libraries.

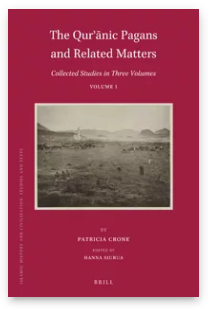

Pages: $\mathrm{x}, 503$ pp.

Language:

English

Subjects:

Religion, Middle

East and Islamic

Studies,

Religion,

Ancient Near

East and Egypt,

Religion, Asian

Studies, Iran \&

Persian Studies,

Middle East and

Islamic Studies,

Religion in

Antiquity,

Religious

Studies

Publisher: Brill

Series:

Islamic History and Civilization,

Volume: 129

E-Book (PDF)

Released online:

10 Jun 2016

ISBN: 978-9O-

04-31928-8

List price

USD $\$ 242.00$

Hardback 
Patricia Crone (1945-2015), Ph.D. (1974), School of Oriental and African Studies, was Professor Emerita at the Institute for Advanced Study, Princeton. Her numerous publications include ISBN: 978-9004-31228-9 List price Meccan Trade and the Rise of Islam (1987); Pre-Industrial Societies (1989); Medieval Islamic Political Thought (2004); and The Nativist Prophets of Early Islamic Iran (2012).

Hanna Siurua (BA, School of Oriental and African Studies; MA, University of Sussex) is a professional editor based in Chicago. She specialises in Islamic and Middle Eastern studies and has edited numerous books and articles in these as well as other fields.

For more information see brill.com

Order information: Order online at brill.com +44330 333 o049 | customerservices@brill.com Submission information: brill.com/authors

Titles published by Brill | Fink, Brill | mentis or Brill | Schöningh: +49(o)71 5413279216 | brill@brocom.de 